AKUNTANSI: Jurnal Akuntansi Integratif

Vol.6 No. 2 Tahun 2020

p-ISSN 2502-5376 e-ISSN 2715-0658

\title{
PERKEMBANGAN 20 TAHUN PENELITIAN MANAJEMEN LABA
}

\author{
Dian Perwitasari ${ }^{1}$ \\ Raras Kirana Wandira ${ }^{2}$ \\ An Nurrahmawati ${ }^{3}$
}

\author{
Universitas Sebelas Maret, Surakarta, Indonesia ${ }^{1,3}$ \\ Universitas Airlangga, Surabaya, Indonesia ${ }^{2}$ \\ Email: dianperwitasari@staff.uns.ac.id ${ }^{1}{\text { raras.kirana.w@feb.unair.ac.id }{ }^{2}}^{2}$ \\ An_nurrahmawati@staff.uns.ac.id ${ }^{3}$
}

\begin{abstract}
ABSTRAK
Studi ini menilai perkembangan publikasi penelitian terhadap manajemen laba. Tujuan utama dari studi ini adalah untuk mengarahkan penelitian dalam rangka menciptakan kerangka teori dan untuk memandu peneliti yang baru di bidang manajemen laba sehingga mereka tahu jurnal dan penulis mana yang dapat dijadikan referensi ketika mempelajari fenomena ini. Studi ini menggunakan beberapa indikator bibliometrik. Semua publikasi penelitian yang terkait dengan manajemen laba dalam database Scopus dianalisis, seperti authorship, jumlah sitasi, tahun publikasi, sumber artikel dan penerbit, institusi dan negara, jenis dan kategori dokumen, bahasa, dan kata kunci penulis. Hasil analisis menujukkan bahwa penelitian terhadap manajemen laba masih dianggap sebagai isu yang menarik dan relevan untuk diteliti.

Kata kunci: Manajemen Laba, Analisis Bibliometrik, Database Scopus

\section{ABSTRACT}

This study assessed the development of research publications on earnings management. The main aim of this study is to orient researches in creating a theoretical framework and to guide researchers who are new in earnings management research so that they know which journals and authors can be used as references when studying this phenomenon. This study uses several bibliometric indicators. All research publications related to the earnings management in the Scopus database are analysed. The authorship, number of citations, year of publication, source of articles and the publisher, institutions and countries, document types and categories, language, and author keywords are identified. The results of these analyses showed that research on earnings management is still considered an interesting and relevant issue to be studied.
\end{abstract}

Keywords: Earnings Management, Bibliometric Analysis, Scopus Database

\section{Pendahuluan}

Selama beberapa dekade terakhir menunjukkan terdapat peningkatan global yang signifikan dalam penelitian akademik tentang fenomena manajemen laba. Model penelitian 
ini kembali merujuk pada seminal work yang dilakukan oleh Schipper (1989) dan Healy \& Wahlen (1999). Namun, peningkatan jumlah penelitian sebagian dapat dikreditkan ke proposal metrik manajemen laba (Jones, 1991; Dechow et al., 1995) dan sebagian dikarenakan meningkatnya kekhawatiran regulator yang dipicu oleh berbagai skandal akuntansi di seluruh dunia. Informasi tentang kualitas laba dalam laporan tahunan perusahaan merupakan informasi yang sangat penting bagi para pengguna laporan keuangan, termasuk investor, kreditor, analis keuangan, debitor, dan pemerintah, ketika membuat keputusan investasi dan peraturan. Dapat diamati bahwa banyak peneliti telah memberikan kontribusi yang signifikan terhadap pengembangan penelitian manajemen laba. Namun, studi tentang kemajuan ilmiah dari pengembangan publikasi atau perspektif sejarah masih belum banyak dilakukan, di mana saat ini, hampir semua sejarah dan pengembangan publikasi di bidang manajemen laba sebagian besar ditemukan dalam bentuk tinjauan literatur naratif dan analisis kuantitatif daripada statistik publikasi. Oleh karena itu, dikarenakan tinjauan literatur naratif bersifat bias (Tranfield, et al., 2003) dan banyaknya analisis yang menggunakan pendekatan kuantitatif, serta jumlah penelitian yang semakin meningkat di bidang manajemen laba, maka studi ini menutup celah tersebut dengan menggunakan analisis bibliometrik.

Sebagai tambahan, studi ini berbeda secara fundamental dari tinjauan literatur sebelumnya tentang manajemen laba, di mana studi ini berfokus pada studi bibliometrik dari penelitian manajemen laba yang telah dipublikasikan di jurnal terindeks internasional bereputasi, dengan mengkuantifikasi artikel dan menggunakan beberapa preferensi ilmiah (yaitu, authorship, jumlah sitasi, sumber jurnal, negara dan lembaga penerbit jurnal, tahun ke tahun publikasi, jenis dan kategori dokumen, bahasa, dan keywords). Studi ini akan memberikan referensi berharga bagi para peneliti terutama dalam pemetaan publikasi penelitian terkait manajemen laba. Rata-rata penelitian yang berkembang sampai saat ini adalah penelitian yang menjadikan perusahaan-perusahaan terdaftar sebagai sampel penelitian mereka untuk mengkaji apakah manajemen laba memang diterapkan oleh perusahaan-perusahaan tersebut dan apa yang menjadi motivasi dari tindakan manajemen laba. Hal ini dilatarbelakangi oleh informasi yang terkandung dalam laba itu sendiri secara tidak langsung menjadi sebuah parameter penting bagi perusahaan, regulator, dan peneliti, serta pustakawan untuk terus mengamati dan menyusun kebijakan, peraturan, penelitian, dan kinerja publikasi dari penelitian manajemen laba. Studi ini disusun sebagai berikut: Bagian 1 pendahuluan yang menyajikan latar belakang adanya suatu peningkatan yang signifikan dalam penelitian akademik tentang fenomena manajemen laba. Bagian 2 tinjauan linteratur yang memberikan ulasan singkat tentang konsep manajemen laba. Bagian 3 membahas metode penelitian yang digunakan dalam studi ini. Bagian 4 menganalisis dan membahas hasil studi. Bagian 5 memberikan simpulan dari studi ini.

\section{Kajian Pustaka}

Berawal dari konsep yang awalnya dikembangkan oleh Schipper (1989) dan Healy \& Wahlen (1999), sebagian besar studi akademik mendefinisikan manajemen laba sebagai suatu tindakan di mana manajemen menggunakan judgement-nya dalam pengungkapan informasi untuk memodifikasi laporan keuangan dengan tujuan untuk mengubah persepsi pemangku kepentingan tentang aktivitas bisnis perusahaan atau untuk mencapai tujuan tertentu. Scott (2009:403) mendefinisikan manajemen laba adalah suatu pilihan kebijakan akuntansi oleh manajer untuk mencapai beberapa tujuan tertentu. Manajemen laba dapat dilakukan dengan beberapa teknik, Martinez dan Castro (2011) mengklasifikasikan tiga jenis teknik pengelolaan laba: earnings management target, yang terjadi untuk meningkatkan atau 
menurunkan laba untuk memenuhi target atau ekspektasi yang ditetapkan; income smoothing, yang bertujuan mengurangi variabilitas laba; dan take a bath accounting, yaitu tindakan manajemen untuk mengurangi laba saat ini dengan tujuan untuk meningkatkan laba di masa depan. Intervensi dalam angka akuntansi ini penting karena laporan keuangan mensintesiskan informasi yang relevan tentang kinerja perusahaan. Selain itu, informasi laba dianggap memainkan peran sentral dalam menilai kinerja perusahaan, sehingga laba sering digunakan sebagai parameter berbagai tujuan.

Dalam perkembangan sejumlah besar literatur, definisi manajemen laba telah banyak berkembang, di mana manajemen laba juga menggabungkan tidak hanya pilihan kebijakan akuntansi yang memengaruhi hasil yang dilaporkan dalam laporan keuangan, tetapi juga untuk memasukkan beberapa keputusan operasional, seperti waktu dari pengeluaran modal dan pengeluaran untuk program pelatihan atau pengaturan tingkat produksi (Martinez, 2011). Menurut kerangka kerja konseptual, Martinez (2011) membagi manajemen laba menjadi dua kategori utama: manajemen laba akrual dan manajemen laba riil. Manajer dapat membuat pilihan yang mempengaruhi keduanya untuk menentukan laba yang akan dilaporkan. Manajemen laba riil sangat terkait dengan keputusan operasional yang berdampak langsung pada arus kas entitas sedangkan akrual hanya memengaruhi waktu pengakuan pendapatan dan beban. Dalam kategori manajemen laba akrual, manajer dapat mengelola laba dengan mengubah proses akrual karena berbagai estimasi dan penilaian manajer disertakan ketika menyiapkan laporan keuangan. Dengan demikian, manajer dapat menerapkan manajemen laba akrual pada akhir tahun fiskal. Pada manajemen laba riil, manajer dapat mengelola laba dengan mengubah waktu atau struktur operasi, investasi, atau keputusan keuangan. Manajemen dengan keputusan operasi (atau manajemen laba riil) dilakukan sepanjang tahun menurut persepsi manajer tentang bagaimana aktivitas entitas akan berkembang selama siklus operasional.

Dua kategori ini memiliki beberapa perbedaan mendasar, terutama di antaranya dampak pada arus kas operasi. Keputusan operasional memiliki dampak langsung pada arus kas entitas sedangkan akrual hanya memengaruhi waktu pengakuan pendapatan dan beban. Definisi ini lebih luas daripada yang biasanya digunakan dalam berbagai literatur, di mana manajemen laba sering digambarkan sebagai tindakan oportunis manajer, di mana manajer mempertimbangkan dan mengambil ospi lain dalam pengelolaan laba dibandingkan dengan memikirkan opsi yang didasarkan pada pilihan akuntansi yang tersedia di standar akuntansi keuangan. Sementara, karakteristik tunggal lainnya tidak selalu menghubungkan manajemen laba dengan konotasi negatif, karena manajemen laba pun dapat memiliki dampak positif dalam keadaan tertentu (Martinez \& Castro, 2011).

Penelitian yang berkembang dewasa ini akhirnya mendefinisikan manajemen laba tidak selalu berarti sebagai bentuk kecurangan akuntansi, karena di akuntansi juga menyediakan beberapa fleksibilitas yang diizinkan oleh standar akuntansi keuangan. Namun, garis pemisah antara manajemen laba yang diizinkan dan bentuk langsung fraud sangat tidak jelas. Baik manajemen laba dan kecurangan akuntansi melibatkan niat untuk memanipulasi informasi, tetapi karena konsep niat itu sendiri sulit untuk dijelaskan, maka hal tersebut tidak boleh menjadi kriteria untuk membedakan fenomena tersebut.

\section{Metode Penelitian}

Analisis bibliometrik terdiri dari penerapan metode statistik untuk menentukan perubahan kualitatif dan kuantitatif dalam topik penelitian ilmiah tertentu, menentukan profil jurnal publikasi pada topik tertentu, dan mendeteksi kecenderungan dalam suatu disiplin (De 
Bakker, et al., 2005). Selain itu, analisis ini memberikan informasi yang berguna bagi para ahli yang ingin mengevaluasi kegiatan ilmiah (Duque, et al., 2006) karena analisis bibliometrik bertindak sebagai panduan untuk mengetahui pergerakan status penelitian dalam topik tertentu. Jenis analisis ini merupakan inovasi metodologis sehubungan dengan tinjauan literatur tradisional (De Bakker, et al., 2005). Penelitian ini menggunakan data dari penelitian yang dipublikasikan dalam database Scopus terkait isu manajemen laba yang diakses pada tanggal 1 Juli 2020. Pertama, kata kunci "earnings management" digunakan untuk mengekstraksi dokumen-dokumen terkait manajemen laba yang diambil dari database Scopus. Pencarian "earnings management" dilakukan mencakup empat bagian, yaitu, title, abstract, keyword. Tahun publikasi yang diambil terbatas pada periode 2000 hingga 30 Juni 2020. Berdasarkan kata kunci ini, total 3436 publikasi telah ditemukan. Namun, publikasi ini juga mengandung dokumen yang tidak terkait erat. Oleh karena itu, hasil ini selanjutnya disempurnakan dengan memilih kategori scopus spesifik: Business, Management, and Accounting sehingga studi ini berhasil menentukan total 2708 dokumen yang telah dipublikasikan terkait manajemen laba.

\section{Hasil dan Pembahasan}

Dalam melakukan analisis bibliometrik terhadap database scopus yang berfokus pada penelitian manajemen laba, studi ini akan mencoba menganalisis semua dokumen yang terkait erat dengan studi manajemen laba yang ditemukan dalam database scopus dalam kurun waktu 20 tahun. Sampel yang dihasilkan terdiri dari 2708 dokumen, termasuk artikel, review, conference artikel, book chapter, note, erratum, buku, conference review, dan beberapa jenis dokumen lainnya.

\section{Jumlah Artikel dan Sitasi}

Berdasarkan 2708 dokumen publikasi yang terkait dengan manajemen laba periode 2000 hingga pertengahan 2020, pertama, studi ini akan menganalisis penulis-penulis yang berkontribusi paling banyak dalam meneliti manajemen laba dan artikel yang paling banyak menerima sitasi. Data menunjukkan bahwa hanya 25 penulis yang telah mempublikasikan lebih dari 5 artikel terkait manajemen laba. Tabel 1 menunjukkan 9 penulis teratas telah mempublikasikan paling sedikit 10 artikel yang berkaitan dengan manajemen laba, diantaranya Habib, Kim, Khrisnan, Lobo, Firth, Cormier, Guan, Jarboui, dan MartinezFerrero. Diikuti di bawahnya, Alhadab, Martinez, Ronen, dan Salehi, masing-masing dengan 9 artikel. Sisanya 12 penulis telah mempublikasikan 6-8 artikel terkait manajemen laba. Di peringkat pertama adalah Ahsan Habib yang berafiliasi di Massey University, Auckland, Albany, New Zealand sebagai seorang professor akuntansi keuangan. Tercatat dalam database scopus, Habib memiliki 94 document yang disitasi oleh 724 dokumen dengan total sitasi 869 dan h-index 17. Minat utama riset Habib adalah pada area penelitian akuntansi berbasis pasar modal, corporate governance dan financial reporting, kualitas audit, corporate finance, dan corporate social responsibility. Habib aktif dalam mempublikasikan artikel-nya ke dalam jurnal bereputasi seperti Accounting \& Business Research, ABACUS, Australian Journal of Management, International Review of Financial Analysis, British Accounting Review, Business \& Society, Journal of Accounting Literature, International Journal of Accounting, Accounting \& Finance, International Journal of Auditing, Journal of Contemporary Accounting \& Economics, and Corporate Governance: An International Review. 
Tabel 1

25 Penulis Teratas Dengan Jumlah Publikasi Artikel Manajemen Laba

\begin{tabular}{|c|l|c|c|l|c|}
\hline No. & \multicolumn{1}{|c|}{ Penulis } & Jumlah Artikel & No. & \multicolumn{1}{|c|}{ Penulis } & Jumlah Artikel \\
\hline 1. & Habib, A. & 13 & 14. & Kanagaretnam, K. & 8 \\
\hline 2. & Kim, J. B. & 12 & 15. & Kim, Y. & 8 \\
\hline 3. & Khrisnan, G. V. & 12 & 16. & Rajgopal, S. & 8 \\
\hline 4. & Lobo, G. J. & 12 & 17. & Saleh, N. M. & 8 \\
\hline 5. & Firth, M. & 11 & 18. & Sundvik, D. & 8 \\
\hline 6. & Cormier, D. & 10 & 19. & Yoon, S. S. & 8 \\
\hline 7. & Guan, L. & 10 & 20. & Chandren, S & 7 \\
\hline 8. & Jarboui, A. & 10 & 21 & Rahman, A. & 6 \\
\hline 9. & Martinez-Ferrero, J. & 10 & 22. & Seybert, N. & 6 \\
\hline 10. & Alhadab, M. & 9 & 23. & Vanstraelen, A. & 6 \\
\hline 11. & Martinez, A. L. & 9 & 24. & Walker, M. & 6 \\
\hline 12. & Ronen, J. & 9 & 25. & Watrin, C. & 6 \\
\hline 13. & Salehi, M. & 9 & & & \\
\hline
\end{tabular}

Judul artikel dan jumlah sitasi yang diterima merupakan dua indikator bibliometrik paling populer yang digunakan untuk menentukan kualitas artikel (Duque et al., 2006). Namun, jumlah sitasi yang diterima oleh suatu artikel mungkin didasarkan pada popularitas penulis atau bidang penelitian daripada relevansi artikel itu sendiri. Tabel 2 menunjukkan daftar penulis yang paling berpengaruh dalam penelitian manajemen laba berdasarkan sitasi tertinggi. Menurut database Scopus, penulis artikel terkait manajemen laba paling produktif dengan sitasi lebih dari 2000 sitasi, pertama adalah Kothari, Laeone, \& Wasley yang telah mempublikasikan artikel berjudul "Performance matched discretionary accrual measures" pada tahun 2005 dengan 2162 sitasi, diikuti yang kedua oleh Graham, Harvey, \& Rajgopal berjudul "The economic implications of corporate financial reporting" pada tahun 2005 dengan 2098 sitasi. Di bawahnya terdapat 8 artikel yang memiliki lebih dari 800 sitasi. Berdasarkan data tersebut, studi ini membuktikan bahwa sebagian besar artikel yang menerima kutipan tertinggi adalah dokumen berbentuk artikel. Hal ini konsisten dengan penelitian yang dilakukan oleh Baltussen dan Kindler (2004) dan Dubin, et al. (1993) yang mengklaim bahwa publikasi artikel dalam jurnal memiliki kecenderungan lebih tinggi untuk disitasi sehingga jumlah sitasi yang diterima suatu artikel juga lebih tinggi. 
Tabel 2

10 Penulis Artikel Manajemen Laba dengan Sitasi Tertinggi

\begin{tabular}{|c|l|l|c|c|}
\hline No. & \multicolumn{1}{|c|}{ Penulis } & \multicolumn{1}{|c|}{ Judul } & $\begin{array}{c}\text { Total } \\
\text { Sitasi }\end{array}$ & $\begin{array}{c}\text { Tahun } \\
\text { Publikasi }\end{array}$ \\
\hline 1. & $\begin{array}{l}\text { Kothari, S. P., } \\
\text { Laeone, A. J., } \\
\text { Wasley, C. E }\end{array}$ & $\begin{array}{l}\text { Performance matched discretionary accrual } \\
\text { measures }\end{array}$ & 2162 & 2005 \\
\hline 2. & $\begin{array}{l}\text { Graham, J. R., } \\
\text { Harvey, C. R., } \\
\text { Rajgopal, S }\end{array}$ & $\begin{array}{l}\text { The economic implications of corporate } \\
\text { financial reporting }\end{array}$ & 2098 & 2005 \\
\hline 3. & $\begin{array}{l}\text { Leuz, C., Nanda, D., } \\
\text { Wysocki, P. D }\end{array}$ & $\begin{array}{l}\text { Earnings management and investor } \\
\text { protection: An International comparison }\end{array}$ & 1998 & 2003 \\
\hline 4. & Klein, A & $\begin{array}{l}\text { Audit committee, board of director } \\
\text { characteristics, and earnings management }\end{array}$ & 1719 & 2002 \\
\hline 5. & $\begin{array}{l}\text { Roychowdhury, S } \\
\text { 6arnings management through real activities } \\
\text { manipulation }\end{array}$ & $\begin{array}{l}\text { Dechow, P., Ge, W., } \\
\text { Schrand, C. }\end{array}$ & $\begin{array}{l}\text { Understanding earnings quality: A review of } \\
\text { the proxies, their determinants and their } \\
\text { consequences }\end{array}$ & 1000 \\
\hline 7. & $\begin{array}{l}\text { Xie, B., Davidson, } \\
\text { W. N., Dadalt, P. J. }\end{array}$ & $\begin{array}{l}\text { Earnings management and corporate } \\
\text { governance: The Role of board and the audit } \\
\text { committee }\end{array}$ & 2006 \\
\hline 8. & $\begin{array}{l}\text { Cohen D. A., Dey, } \\
\text { A., Lys, T. Z. }\end{array}$ & $\begin{array}{l}\text { Real and accrual based earnings management } \\
\text { in the pre- and post-sarbanes-oxley periods }\end{array}$ & 941 & 2008 \\
\hline 9. & $\begin{array}{l}\text { Watss, R. L. } \\
\text { Conservatism in accounting part I: } \\
\text { Explanations and implications }\end{array}$ & 898 & 2003 \\
\hline 10. & $\begin{array}{l}\text { Barth, M. E., } \\
\text { Landsman, W. R., } \\
\text { Lang, M. H. }\end{array}$ & $\begin{array}{l}\text { International accounting standards and } \\
\text { accounting quality }\end{array}$ & 892 & 2008 \\
\hline
\end{tabular}

Selain itu, dapat juga diperhatikan bahwa hampir seluruh artikel yang memiliki banyak sitasi dalam bidang ini secara logis juga tergantung pada tahun publikasi. Dalam hal ini, orang dapat merasakan bahwa artikel mereka biasanya tidak atau belum disitasi dalam 1 atau 2 tahun setelah artikel itu dipublikasi dan umumnya akan memakan waktu antara 4 sampai 10 tahun untuk disitasi. Namun, jumlah sitasi dapat meningkat atau menurun dikarenakan jumlah sitasi dapat mencapai puncaknya (Slyder et al., 2011). Artikel yang paling banyak dikutip adalah artikel Kothari, et al. (2005) yang meneliti hubungan antara kinerja dan ukuran discretionary accrual, menemukan bahwa fitur utama dari ukuran discretionary accrual adalah ukuran ini cocok untuk mengukur kinerja akrual perusahaan di mana kecocokan tersebut sering berdasar pada return on asset dan industri perusahaan. Discretionary accrual sering digunakan peneliti sebagai ukuran untuk mendeteksi terjadinya manajemen laba, di mana untuk menentukan discretionary accrual dapat menggunakan jones model dan modified jones model. Modified jones model. dianggap yang paling popular di antara model yang lainnya, namun kesimpulan yang bisa diambil adalah seluruh model pengukuran discretionary accrual memiliki kelemahan masing-masing (Dechow et al., 1995). Walaupun di penelitian-penelitian sebelumnya menunjukkan bawah kedua model Jones tersebut kurang tepat jika digunakan pada penelitian dengan sampel non acak (Dechow et al., 1995 \& Guay, et al., 1996), namun Kothari, et al. (2005) juga sependapat dengan Dechow et al. (1995), bahwa penggunaan modified jones model lebih disarankan selama dihubungkan dengan kinerja yang sesuai yaitu kinerja akrual. 


\section{Tahun Publikasi}

Gambar 1 menunjukkan jumlah publikasi di rentang tahun 2000 hingga 30 Juni 2020. Data menunjukkan adanya tren minat studi tentang manajemen laba semakin meningkat. Walaupun di beberapa tahun tertentu mengalami sedikit penurunan jumlah publikasi, namun jika dilihat pada Gambar 3 menyajikan grafik tren kenaikan dari tahun 2000 dengan total 25 publikasi sampai dengan 2019 dengan total 316 publikas. Di tahun 2020 hanya terdapat 160 total publikasi dikarenakan data yang terkumpul adalah data yang berakhir pada tanggal 30 Juni 2020. Minat yang berkelanjutan ini menunjukkan bahwa manajemen laba masih menjadi isu yang relevan dan menarik untuk diteliti. Selain itu, para peneliti masih dapat menempatkan banyak gap dari penelitian-penelitian sebelumnya, misalnya perbedaan manajemen laba antara negara maju dan negara berkembang, indikasi manajemen laba sebelum dan sesudah perubahan peraturan pajak dan IPO, financial distress, dan cara manajemen laba dapat memengaruhi pengambilan keputusan untuk investor, kreditor, regulator, dan pengambil keputusan lainnya. Salah satu contoh artikel terbaru yang diambil dari database Scopus di tahun 2020 adalah "Financial distress, internal control, and earnings management: Evidence from China" yang dipublikasikan di Journal of Contemporary Accounting and Economics. Artikel ini meneliti bagaimana financial distress memengaruhi pilihan metode manajemen laba yang akan digunakan dan bagaimana kualitas internal control memoderasi hubungan tersebut. Hasil penelitian tersebut menunjukkan bahwa ketika perusahaan mengalami financial distress, perusahaan cenderung lebih melakukan manajemen laba akrual daripada manajemen laba riil dan internal control mampu memberikan efek moderasi hubungan antara financial distress dan manajemen laba dengan menahan atau mengurangi kecenderungan manajemen laba baik akrual maupun riil (Li, et al., 2020).

\section{Gambar 1}

\section{Tren Publikasi Artikel Manajemen Laba Berdasarkan Tahun Publikasi}

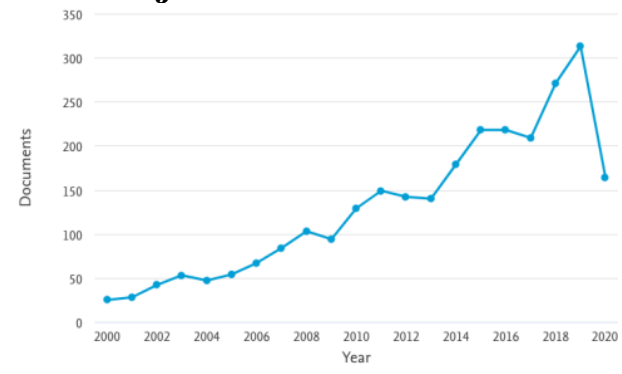

\section{Sumber Artikel dan Penerbit}

Dalam mempublikasikan artikel, penting untuk mengetahui dan memutuskan di mana artikel akan dipublikasikan ke jurnal tujuan. Penulis yang memasukkan artikelnya di jurnal bereputasi tentunya berharap artikelnya akan dibaca dan disitasi oleh peneliti lain ketika menyusun tinjauan literatur. Tabel 3 menyajikan 10 sumber artikel atau jurnal yang paling banyak mempublikasikan artikel tentang manajemen laba. Jurnal yang paling populer di bidang ini adalah Accounting Review dengan total 120 artikel. Lebih dari 70 artikel ada dalam Journal of Accounting and Economics, Corporate Ownership and Control, Journal of Business Finance, and Journal of Accounting and Public Policy. Sementara jurnal yang lain telah meneribitkan lebih dari 50 artikel.

Hirsch (2005) mengusulkan indikator kinerja penelitian yang berlaku di tingkat mikro yaitu Hirsch Index atau h-index. H-index menggunakan dasar penghitungan jumlah artikel jurnal (h) yang telah menerima setidaknya $h$ sitasi. Index ini mengukur baik produktivitas ilmiah jurnal maupun impact ilmiah jurnal yang berlaku untuk peneliti, negara, dan lainnya. 
Index ini juga merupakan ukuran sederhana penghitungan kuantitas dan visibilitas publikasi jurnal (Bornmann \& Daniel, 2007; Egghe \& Rousseau, 2006; Van Raan, 2006). Misalnya, jurnal memiliki h-index 40, artinya jurnal telah telah menerbitkan 40 artikel yang masingmasing artikel telah menerima setidaknya 40 sitasi. Karena itu, h-index jurnal tidak pernah bisa berkurang. Sebaliknya, indeks ini umumnya akan meningkat ketika penelitian baru diterbitkan dan menarik sitasi (Cronin \& Meho, 2006; Hirsch, 2005). H-index 0 mencirikan jurnal tidak aktif (Glanzel, 2006) yang bahkan jika mereka telah mempublikasikan setidaknya satu artikel, tidak memiliki impact yang terlihat. Dengan demikian, h-index adalah estimator yang kuat untuk total impact dari kontribusi jurnal dalam bidang penelitian tertentu (Hirsch, 2005). Tabel 3 menunjukkan terdapat 3 jurnal yang memiliki h-index lebih dari 100. Pertama, Journal of Business Ethics dengan total h-index sebanyak 168 dan selanjutnya jurnal Accounting Review dan Journal of Accounting and Economics dengan masing-masing memiliki h-index sebanyak 143. Hal ini menunjukkan bahwa para peneliti masih tertarik untuk meneliti isu manajemen laba dengan mensitasi artikel-artikel yang berasal dari jurnal yang bereputasi.

Tabel 3

10 Sumber Artikel Teratas Berdasarkan Jumlah Publikasi Artikel

\begin{tabular}{|c|l|c|c|c|}
\hline No. & \multicolumn{1}{|c|}{ Sources Title } & $\begin{array}{c}\text { No. of } \\
\text { Artikels }\end{array}$ & $\begin{array}{c}\text { H- } \\
\text { index }\end{array}$ & Q \\
\hline 1. & $\begin{array}{l}\text { Accounting Review } \\
\text { Publisher: American Accounting Association }\end{array}$ & 120 & 143 & Q1 \\
\hline 2. & $\begin{array}{l}\text { Journal of Accounting and Economics } \\
\text { Publisher: Elsevier BV }\end{array}$ & 79 & 143 & Q1 \\
\hline 3. & $\begin{array}{l}\text { Corporate Ownership and Control } \\
\text { Publisher: Virtus Interpress }\end{array}$ & 72 & 72 & Q1 \\
\hline 4. & $\begin{array}{l}\text { Journal of Business Finance and Accounting } \\
\text { Publisher: Blackwell Publishing Inc. }\end{array}$ & 71 & 70 & Q1 \\
\hline 5. & $\begin{array}{l}\text { Journal of Accounting and Public Policy } \\
\text { Publisher: Elsevier BV }\end{array}$ & 65 & 90 & Q1 \\
\hline 6. & $\begin{array}{l}\text { Contemporary Accounting Research } \\
\text { Publisher: Willey-Blackwell }\end{array}$ & 63 & 39 & Q1 \\
\hline 7. & $\begin{array}{l}\text { Review of Quantitative Finance and Accounting } \\
\text { Publisher: Springer New York }\end{array}$ & 62 & 67 & Q1 \\
\hline 8. & $\begin{array}{l}\text { Review of Accounting Studies } \\
\text { Publisher: Springer New York }\end{array}$ & 55 & 52 & Q1 \\
\hline 9. & $\begin{array}{l}\text { Managerial Auditing Journal } \\
\text { Publisher: Emerald Group Publishing Ltd. }\end{array}$ & 51 & 168 & Q1 \\
\hline 10. & $\begin{array}{l}\text { Journal of Business Ethics } \\
\text { Publisher: Springer Netherlands }\end{array}$ & & & \\
\hline
\end{tabular}

Selain itu, Scopus juga menggunakan parameter pemeringkatan jurnal yaitu Scimago Journal \& Country Rank atau SJR. SJR dihitung berdasarkan jumlah sitasi rata-rata per artikel yang dipublikasikan dalam suatu jurnal dalam kurun waktu tiga tahun terakhir dari database Scopus. Dalam menilai jurnal, Scopus membuat klasterisasi kualitas jurnal yang terbagi menjadi 4 Quartile, di mana Quartile Satu (Q1) adalah klaster paling tinggi dari segi kualitas jurnal, kemudian diikuti Q2, Q3, dan Q4. Pengklasterisasian ini juga dapat membantu para penulis untuk menentukan jurnal mana artikel mereka akan dipublikasikan untuk meningkatkan jumlah sitasi. Tabel 3 juga menyajikan bahwa dari 10 jurnal teratas 
tersebut menunjukkan 9 dari 10 berasal dari Q1 dan 1 jurnal berada di Q4 yaitu Corporate Ownership and Control. Berdasarkan database Scopus, penulis melihat bahwa cakupan jurnal tersebut dihentikan di Scopus sejak tahun 2016. Topik manajemen laba masih menjadi isu yang menarik untuk diteliti karena jurnal-jurnal yang bereputasi masih banyak mempublikasikan artikel tentang manajemen laba dari berbagai perspektif. Accounting Review menjadi jurnal bereputasi yang menampung penelitian manajemen laba terbanyak. Dilihat dari CiteScore di database Scopus, Accounting Review menempati peringkat ke 11 dari 270 jurnal kategori finance dan peringkat ke 6 dari 154 jurnal kategori accounting, dengan total CiteScore 2019 sebesar 7.1. CiteScore ini digunakan untuk menilai seberapa bereputasi jurnal internasional yang terindeks Scopus. Hal ini tentu saja berguna ketika penulis membuat keputusan jurnal internasional mana yang akan di-submit.

\section{Institusi dan Negara}

Berdasarkan data yang ditemukan, Tabel 4 menyajikan hasil dari 10 teratas institusi/universitas yang berkontribusi dalam publikasi artikel terkait manajemen laba. Secara umum, data menunjukkan 160 universitas/institusi yang berbeda telah memberikan kontribusi artikel penelitian di bidang manajemen laba. Berdasarkan jumlah publikasi artikel, New York University berkontribusi 30 artikel sehingga menjadi universitas yang memiliki kontribusi tertinggi terkait jumlah artikel manajemen laba. Bahkan diperkuat juga bukti bahwa negara tempat intitusi/universitas tersebut berada juga menempati posisi pertama yaitu Amerika Serikat. Diikuti Hong Kong Polytechnic University dan Universiti Utara Malaysia memberikan kontribusi masing-masing 33 artikel dan 30 artikel. Sisanya rata-rata berkontribusi 22-27 artikel yang tersebar di berbagai negara.

Tabel 4

10 Institusi Teratas yang Memiliki Publikasi Tentang Manajemen Laba

\begin{tabular}{|c|l|c|}
\hline No. & \multicolumn{1}{|c|}{ Institusi } & Jumlah Publikasi \\
\hline 1. & New York University & 35 \\
\hline 2. & Hong Kong Polytechnic University & 33 \\
\hline 3. & Universiti Utara Malaysia & 30 \\
\hline 4. & University of Houston & 27 \\
\hline 5. & City University of Hong Kong & 26 \\
\hline 6. & University of Washington, Seattle & 25 \\
\hline 7. & University of Sfax & 25 \\
\hline 8. & Shanghai University of Finance and Economics & 23 \\
\hline 9. & Monash University & 22 \\
\hline 10. & University of New South Wales UNSW Australia & 22 \\
\hline
\end{tabular}

Salah satu penjelasan untuk variasi publikasi penelitian di antara institusi/universitas ini adalah pengeluaran diferensial dan dukungan penelitian oleh masing-masing institusi/universitas. Studi Man, et al. (2004) dapat menjadi dasar untuk mendukung gagasan ini karena mereka melaporkan bahwa institusi/universitas yang berbeda akan memiliki sistem penghargaan/reward yang berbeda untuk memperhitungkan output/hasil publikasi. Dengan demikian, reward system ini menjadi salah satu sistem yang berkontribusi pada lebih banyaknya jumlah publikasi penelitian ke dalam jurnal yang bereputasi. Oleh karena itu, universitas/institusi yang memiliki lebih banyak publikasi penelitian, secara umum dapat dianggap lebih baik dalam hal memberikan dukungan keuangan, bantuan penelitian atau sistem praktik terbaik untuk mendorong lebih banyak publikasi penelitian. Berdasarkan website dari New York University, New York University menempati peringkat kedua di 
antara universitas swasta untuk pendanaan research and development di bidang humaniora. New York University merupakan universitas swasta yang mengedepankan penelitian modern sebagai salah satu poin keunggulan yang dimiliki. Dalam misi riset modernnya, New York University memiliki dual mission yaitu untuk mendidik mahasiswanya dan untuk menemukan new knowledge melalui beasiswa. Dua misi tersebut saling menguatkan dan memberi informasi satu sama lain, di mana para mahasiswa dalam banyak hal diajarkan para periset senior/discoverers, yang kemudian riset mahasiswa tersebut dibahas dalam suatu course/classroom sebagai wadah untuk pertukaran gagasan untuk membantu mempertajam penelitian. Bahkan dalam NYU Framework 2031 menyatakan "A great research university produces, preserves, and transmits new ideas, insights, and knowledge. Its basic research activities promote and nurture scientific progress, develop artistic and creative expression, and sustain an informed democratic society and its political life".

Tabel 5

10 Negara Teratas yang Berkontribusi Publikasi Terkait Manajemen Laba

\begin{tabular}{|c|l|c|}
\hline No. & \multicolumn{1}{|c|}{ Negara } & Jumlah Artikel \\
\hline 1. & Amerika Serikat & 1102 \\
\hline 2. & China & 235 \\
\hline 3. & Australia & 199 \\
\hline 4. & United Kingdom & 153 \\
\hline 5. & Canada & 148 \\
\hline 6. & Malaysia & 115 \\
\hline 7. & Korea Selatan & 113 \\
\hline 8. & Hongkong & 106 \\
\hline 9. & Spanyol & 106 \\
\hline 10. & Indonesia & 94 \\
\hline
\end{tabular}

Tabel 5 menunjukkan 10 negara teratas yang telah mempublikasikan setidaknya 94 artikel manajemen laba. Dapat diamati bahwa publikasi artikel manajemen laba paling didominasi oleh Amerika Serikat dengan memimpin jauh di antara negara lainnya yaitu sebanyak 1102 artikel, diikuti oleh Cina dengan 235 artikel. Hasil ini menunjukkan bahwa Amerika Serikat memiliki impact yang besar dalam hal publikasi penelitian terkait dengan manajemen laba. Amerika Serikat mencetak jumlah publikasi penelitian yang lebih tinggi karena populasi yang besar dan sumber daya keuangan yang tersedia untuk komunitas ilmiah (Man, et al., 2004). Selain itu, mereka juga mengklaim bahwa pengeluaran diferensial untuk penelitian antar negara juga diperhitungkan untuk semua variasi dalam keluaran publikasi di seluruh dunia. Gagasan ini juga konsisten dengan Rahman dan Fukui (2003), yang mengklaim bahwa jumlah publikasi penelitian dari masing-masing negara sebagian besar bergantung pada produk nasional bruto per kapita dan pengeluaran dialokasikan untuk penelitian dan pengembangan. American Accounting Association menjadi salah satu sponsor pendanaan terbesar di bidang penelitian manajemen laba di Amerika Serikat. Oleh karena itu, hal-hal tersebut menjadi jawaban atas dominasi Amerika Serikat akan jumlah publikasi tersebut. Dalam hal ini, diyakini bahwa ketika dukungan keuangan untuk penelitian itu kuat, maka tingkat produktivitas penelitian akan semakin meningkat, dibandingkan dengan negara lain yang menghabiskan lebih sedikit untuk pendanaan penelitian.

Di urutan kedua, China juga secara produktif ikut berkontribusi artikel di bidang ini. Hal ini disebut karena dilatarbelakangi ketika Cina telah mengambil alih posisi Jepang sebagai ekonomi terbesar kedua dan kapitalisasi pasar bursa sahamnya pun saat ini juga 
menempati urutan kedua. Sementara, sejumlah besar studi yang telah menginvestigasi aktivitas manajemen laba di perusahaan-perusahaan yang terdaftar di negara-negara maju, terutama Amerika Serikat, kini fokus tersebut baru-baru ini juga mulai bergeser ke China, terutama karena banyak peneliti yang telah mempelajari motivasi tindakan manajemen laba pada perusahaan yang terdaftar, pengukuran manajemen laba, hubungan corporate governance dan manajemen laba, dan mitigasi manajemen laba di Cina. National Natural Science Foundation of China di China menjadi lembaga sponsor pendanaan terbesar yang telah membantu pendanaan pada 66 artikel manajemen laba di Scopus. Diikuti Social Sciences and Humanities Research Council of Canada yang juga telah membantu pendanaan pada 22 artikel manajemen laba di Scopus yang membuat Canada termasuk dalam 10 negara teratas yang ikut berkontribusi dalam publikasi terkait manajemen laba. Hal yang cukup mengejutkan dan diapresiasi adalah Indonesia. Indonesia termasuk dalam 10 negara teratas yang berkontribusi dalam publikasi terkait manajemen laba di urutan 10. Hal ini membutikan para peneliti di Indonesia masih memberikan perhatian besar terkait isu manajemen laba terutama pada perusahaan yang terdaftar go public.

5. Jenis dan Kategori Dokumen

Studi ini juga menganalisis distribusi jenis dan kategori dokumen yang digambarkan dalam Gambar 2.

\section{Gambar 2 Jenis Dokumen}

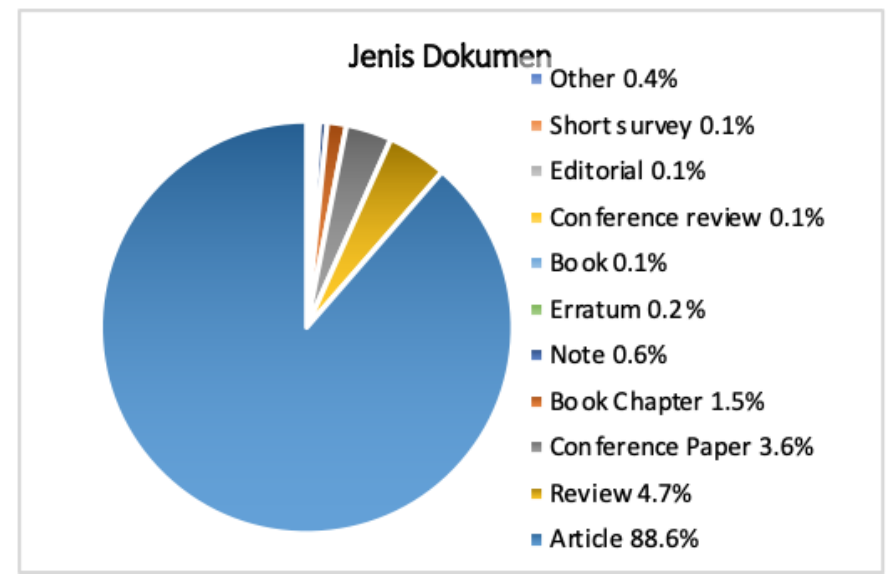

Ditemukan bahwa ada 10 jenis dokumen yang terkait dengan manajemen laba. Berdasarkan database Scopus, artikel adalah jenis dokumen terbanyak yaitu 2396 artikel (88,6\%). Diikuti oleh 128 review (4,7\%) dan 98 conference artikel (3,6\%). Sisanya book chapter, note, erratum, buku, conference review, editorial, short survey, retracted, dan undefined berada di bawah 50 dokumen $(3,1 \%)$. 


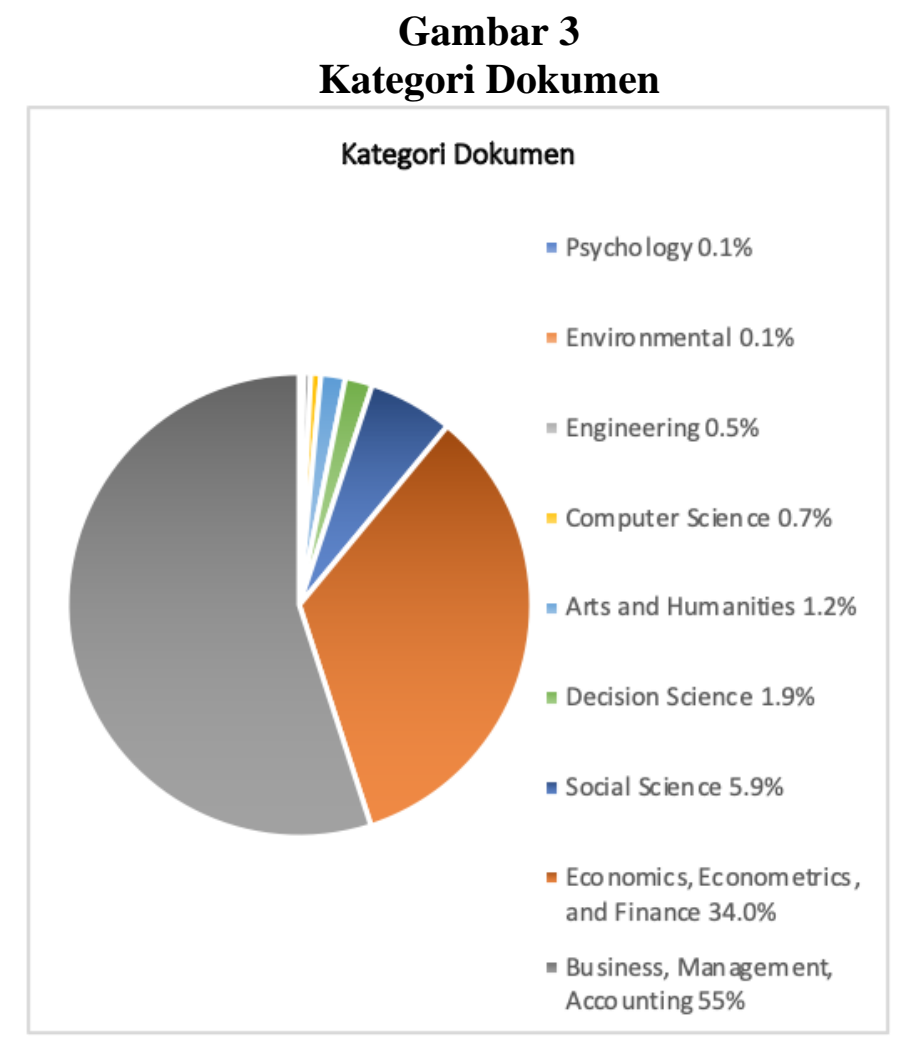

Gambar 3 menunjukkan jumlah dokumen yang dipublikasikan dalam kategori ilmu yang berbeda. Dokumen terkait manajemen laba terbanyak ditemukan dalam bidang kategori Business, Management, and Accounting (55\%) dan Economy, Econometric, and Finance (34\%). Sisanya diminati di kategori ilmu yang lain (11\%). Diagram ini mengungkapkan perbedaan besar antara jumlah dokumen dalam Business, Management, and Accounting dan jumlah dokumen di kategori ilmu lain (Lee, et al., 2007). Temuan ini menyiratkan bahwa lebih dari setengah penelitian manajemen laba adalah topik yang masih sangat relevan di kategori Business, Management, and Accounting.

\section{Bahasa dan Kata Kunci}

Di sisi lain, studi ini juga menganalisis distribusi terkait bahasa yang digunakan dalam dokumen publikasi di database Scopus. Tabel 6 menunjukkan jumlah publikasi manajemen laba berdasarkan bahasa. Seperti yang diharapkan, bahasa yang paling umum digunakan adalah bahasa Inggris yaitu 97,3\% (2636 dokumen) dari total dokumen publikasi. Bahasa kedua yang paling umum adalah China (19 dokumen). Pola ini sangat lazim karena hampir semua jurnal utama adalah jurnal berbahasa Inggris, bahasa yang memang harus diketahui semua peneliti dalam komunitas akademik global modern. 
Tabel 6

8 Bahasa yang Digunakan oleh Penulis

\begin{tabular}{|l|l|l|}
\hline No. & Bahasa & $\begin{array}{l}\text { Jumlah } \\
\text { Artikel }\end{array}$ \\
\hline 1. & United Kingdom & 2636 \\
\hline 2. & Perancis & 19 \\
\hline 3. & Spanyol & 18 \\
\hline 4. & China & 13 \\
\hline 5. & Portugis & 10 \\
\hline 6. & Jerman & 8 \\
\hline 7. & Lithuania & 3 \\
\hline 8. & Melayu & 1 \\
\hline
\end{tabular}

Tabel 7

Kata kunci yang digunakan oleh penulis

\begin{tabular}{|c|l|c|}
\hline No. & \multicolumn{1}{|c|}{ Keyword } & Freq \\
\hline 1. & Earnings Management & 1572 \\
\hline 2. & Corporate Governance & 313 \\
\hline 3. & Discretionary Accruals & 205 \\
\hline 4. & Real Earnings Management & 158 \\
\hline 5. & Earnings Quality & 124 \\
\hline 6. & Audit Quality & 84 \\
\hline 7. & IFRS & 77 \\
\hline 8. & Accruals & 74 \\
\hline 9. & Earnings & 74 \\
\hline 10. & Financial Reporting & 69 \\
\hline
\end{tabular}

Tabel 7 menyajikan daftar 10 kata kunci paling sering digunakan oleh penulis dalam dokumen publikasi mereka terkait manajemen laba. Dapat diamati bahwa kata kunci yang paling sering digunakan oleh penulis di bidang ini adalah "Earnings Management" yang digunakan sebanyak 1572 kali dan 3 kata kunci lain yang sering digunakan yaitu "Corporate Governance" (313 kali), dan "Discretionary Accruals" (205 kali). Corporate Governance sering dijadikan sebagai kata kunci dalam penelitian yang mengangkat isu manajemen laba karena corporate governance merupakan salah satu mekanisme perusahaan untuk mengurangi tindakan manajemen laba. Sementara, "Discretionary Accruals" sering dijadikan sebagai kata kunci dalam penelitian manajemen laba karena discretionary accruals sering dijadikan ukuran dalam mengestimasi manajemen laba.

Melihat beberapa kata kunci tersebut, dapat diasumsikan bahwa kecenderungan artikel penelitian di bidang manajemen laba telah melibatkan beberapa rentang fokus penelitian dan literatur yang beragam. Hal ini menunjukkan bahwa penelitian manajemen laba masih menawarkan beberapa cara untuk dieksplorasi. Gagasan ini didukung oleh Fu dan Ho (2012) yang mengklaim bahwa tren penelitian dapat dilihat dengan menganalisis secara kuantitatif frekuensi kata kunci penulis yang dapat memberikan gambaran yang cukup mutakhir terkait subjek penelitian.

\section{Kesimpulan}

Studi ini mengevaluasi perkembangan publikasi penelitian terkait manajemen laba berdasarkan beberapa indikator bibliometrik. Publikasi penelitian dalam studi ini diekstraksi dari database Scopus menggunakan kata kunci. Berdasarkan kata kunci "earnings management" dan terbatas pada kategori yang telah ditentukan, penelitian ini berhasil mengidentifikasi 2708 dokumen publikasi. Studi ini menemukan bahwa artikel yang paling banyak disitasi terkait dengan manajemen laba adalah "Performance matched discretionary accrual measures" yang diteliti oleh Kothari, et al. (2005) dan menerima 2162 sitasi. Penulis yang banyak mempublikasikan artikel terkait manajemen laba adalah Habib, A dengan jumlah 13 artikel. Studi ini juga mengamati bahwa Accounting Review adalah jurnal yang paling popular yang dijadikan jurnal tujuan publikasi oleh para penulis di bidang ini. New York University di Amerika menjadi institusi yang menghasilkan paling banyak artikel terkait manajemen laba. Hal ini relevan dengan data yang 
menunjukkan bahwa Amerika menjadi negara pemasok paling banyak artikel manajemen laba. Terkait Bahasa, 98\% dari total artikel yang dianalisis menggunakan Bahasa Inggris. Terakhir, hasil menunjukkan kata kunci yang digunakan oleh penulis terkait penelitian manajemen laba sangat bervariatif, dan yang paling sering adalah "earnings management". Hasil analisis ini dapat mencerminkan pentingnya artikel dalam tinjauan literatur dan memberikan beberapa wawasan ke dalam landscape penelitian di bidang ini. Selain itu, diharapkan juga bahwa temuan ini juga akan memengaruhi mereka untuk membawa lebih banyak perhatian pada publikasi penelitian di bidang ini. Studi ini memiliki sejumlah keterbatasan, pertama, studi ini hanya menganalisis dokumen publikasi terkait manajemen laba yang hanya dipublikasikan di jurnal terindeks scopus (database Scopus), maka untuk langkah penelitian selanjutnya para peneliti dapat mengembangkan analisis bibliometrik dengan database selain Scopus, misalnya Web of Science. Kedua, studi ini menggunakan rentang waktu 20 tahun, tidak dari tahun awal atau semua tahun, karena penulis menggunakan dasar bahwa model penelitian ini kembali merujuk pada seminal work yang dilakukan oleh Schipper (1989) dan Healy \& Wahlen (1999), sehingga peneliti mengambil rentang waktu publikasi dari tahun 2000 sampai 30 Juni 2020. Dalam hal ketercapaian jumlah sitasi, ada kemungkinan/kecenderungan penulis untuk self-citation, atau kecenderungan mensitasi artikel-artikel yang ada di jurnal tempat mereka akan melakukan publikasi. Selain itu artikel yang baru dipublikasikan kemungkinan belum mendapatkan banyak sitasi sebanyak artikel yang sudah bertahun-tahun dipublikasi, dikarenakan artikelartikel yang baru tidak memiliki cukup waktu untuk mencapai sitasi tinggi dibandingkan artikel-artikel yang lebih tua.

\section{Daftar Pustaka}

Baltussen, A., \& Kindler, C. H. 2004. Citation Classics in Anesthetic Journals. Intensive care medicine, 30(5), 902-910.

Bornmann, L., \& Daniel, H. D. 2007. What Do We Know About The H-Index? Journal of the American Society for Information Science and Technology, 58(9), 1381-1385.

Cronin, B., \& Meho, L. 2006. Using the H-Index to Rank Influential Information Scientists. Journal of the American Society for Information Science and Technology, 57(9), 1275-1278.

De Bakker, F. G., Groenewegen, P., \& Den Hond, F. 2005. A Bibliometric Analysis of 30 Years of Research and Theory on Corporate Social Responsibility and Corporate Social Performance. Business \& Society, 44(3), 283-317.

Dechow, P. M., Sloan, R. G., \& Sweeny, A. P. 1995. Detecting Earnings Management. The Accounting Review, 70(2), 193-225.

Dubin, D., Häfner, A. W., \& Arndt, K. A. 1993. Citation Classics in Clinical Dermatologic Journals: Citation Analysis, Biomedical Journals, and Landmark Articles, 19451990. Archives of Dermatology, 129(9), 1121-1129.

Duque, O. E. J., Cervera T. A., \& Romero, R. C. 2006. A Bibliometric Analysis of Models Measuring the Concept of Perceived Quality in Providing Internet Service. Innovar, 16(28), 223-243.

Egghe, L., \& Rousseau, R. 2006. An Informetric Model for the Hirsch-Index. Scientometrics, 69(1), 121-129. 
Fu, H. Z., \& Ho, Y. S. 2012. Bibliometric Analysis of Thermodynamic Research: A Science Citation Index Expanded-Based Analysis. INTECH Open Access Publisher.

Glanzel, W. 2006. On the Opportunities and Limitations of the H-Index. Science Focus, $1(1), 10-11$.

Hirsch, J. E. 2005. An Index to Quantify an Individual's Scientific Research Output. Proceedings of the National Academy of Sciences, 102(46), 16569-16572.

Healy, P. M., \& Wahlen, J. M. 1999. A Review of the Earnings Management Literature and Its Implications for Standard Setting. Accounting Horizons, 13(4), 365-383.

Jones, J. J. 1991. Earnings Management During Import Relief Investigations. Journal of Accounting Research, 29(2), 193-228.

Kothari, S. P., Laeone, A. J., \& Wasley, C. E. 2005. Performance Matched Discretionary Accrual Measures. Journal of Accounting and Economics, 39(1), 163-197.

Li, Y., Li, X., Xiang, E., \& Djajadikerta, H. G. 2020. Financial Distress, Internal Control, and Earnings Management: Evidence from China. Journal of Contemporary Accounting and Economics, 16(3), 100210

Lee, S. M., Ribeiro, D., Olson, D. L., \& Roig, S. 2007. The Importance of the Activities of Service Business in the Economy: Welcome to the Service Business. An International Journal Service Business, 1(1), 1-5.

Man, J. P., Weinkauf, J. G., Tsang, M., \& Sin, J. H. D. D. 2004. Why Do Some Countries Publish More Than Others? An International Comparison of Research Funding, English Proficiency and Publication Output in Highly Ranked General Medical Journals. European Journal of Epidemiology, 19(8), 811-817.

Martinez, A. L. 2011. Do Corporate Governance Special Listing Segments and Auditing Curb Real Earnings Management and Accrual-Based Earnings Management? Evidence from Brazil. Universo Contabil, 7(4), 98-117.

Martinez, A. L., \& Castro, M. A. R. 2011. The smoothing hypothesis, stock returns and risk in Brazil. BAR - Brazilian Administration Review, 8(1), 1-20.

New York University. 2008. NYU Framework 2031. Download pada tanggal 8 Juli 2020, https://www.nyu.edu/

Rahman, M., \& Fukui, T. (2003). Biomedical research productivity. International Journal of Technology Assessment in Health Care, 19(1), 249-252.

Schipper, K. (1989). Commentary on Earnings Management. Accounting Horizons, 3(4), 91-102.

Scott, W. 2009. Financial ccounting theory. Ontario: Prentice-Hall Canada Inc.

Slyder, J. B., Stein, B. R., Sams, B. S., Walker, D. M., Beale, B. J., Feldhaus, J. J., \& Copenheaver, C. A. (2011). Citation Pattern and Lifespan: A Comparison of Discipline, Institution, and Individual. Scientometrics, 89(3), 955-966.

Tranfield, D., Denyer, D., and Smart, P. (2003). Towards a Methodology for Developing Evidence-Informed Management Knowledge by Means of Systematic Review. British Journal of Management, 14(3), 207-222.

Van Raan, A. F. 2006. Comparison of the Hirsch-index with standard bibliometric indicators and with peer judgment for 147 chemistry research groups. Scientometrics, 67(3), 491-502. 